\title{
The effect of hemofilter, preoperative and intraoperative methylprednisolone on complications after open heart surgery
}

\author{
Supomo ${ }^{1}$, Teguh Aryandono², Marsetyawan Soesatyo ${ }^{3}$, Paulus Sudiharto ${ }^{4}$ \\ ${ }^{1}$ Thoracic and Cardiovascular Surgery Division, Department of Surgery, ${ }^{2}$ Oncologic \\ Surgery Division, Department of Surgery, Faculty of Medicine, Universitas Gadjah Mada/ \\ Dr. Sardjito General Hospital, ${ }^{3}$ Department of Histology and Cellular Biology, Faculty of \\ Medicine, Universitas Gadjah Mada, ${ }^{4}$ Neuro Surgery Division, Department of Surgery, \\ Faculty of Medicine, Universitas Gadjah Mada/Dr. Sardjito General Hospital, Yogyakarta
}

DOI: http://dx.doi.org/10.19106/JMedSci004904201704

\section{ABSTRACT}

Complications after open heart surgery may threaten patient's survival rate. The intraoperative methylprednisolone administration alone shows controversial results on open heart surgery complications. Similarly, the intraoperative and preoperative methylprednisolone administration as well as the use of hemofilter in open heart surgery is still controversial. This study aimed to evaluate the effect of hemofilter, preoperative and intraoperative methylprednisolone administration on complications following open heart surgery. This was a Prospective Randomized Open-Blinded Evaluation (PROBE) experimental study. Ninety-five patients who had open heart surgery in Dr. Sardjito General Hospital, Yogyakarta, and Integrated Cardiac Care of Dr. Cipto Mangunkusumo General Hospital, Jakarta within the period of December 2011 to May 2012 were involved in this study. The patients were divided into two groups i.e. group A, 48 patients received methylprednisolone $15 \mathrm{mg} / \mathrm{kg}$ intraoperatively, methylprednisolone $5 \mathrm{mg} / \mathrm{kg}$ preoperatively, and hemofilter, while group B, 47 patients received methylprednisolone $15 \mathrm{mg} / \mathrm{kg}$ intraoperatively alone. From the total 95 patients, we found 26 (27.4\%) patients experienced complications i.e. 19 in group B (40.4\%) and 7 in group A $(14.6 \%)$. The differences of the complications were statistically significant $(p<0.05$; $\mathrm{OR}=3.97 ; 95 \% \mathrm{Cl}=1.476-10.71$ ). Complications risk decreased by $63.9 \%$ in the group A compared to the group B with the hazard ratio of 3.2. In conclusion, the application of hemofilter, preoperative and intraoperative methylprednisolone might decrease the risk of complications after open heart surgery.

\section{ABSTRAK}

Komplikasi paska bedah jantung terbuka dapat mempengaruhi angka harapan hidup pasien. Pemberian intraoperatif metilpredinsolon saja untuk mencegah komplikasi paska bedah jantung terbuka masih menunjukkan hasil yang kontroversial. Pemberian metilprednisolon preoperatif dan intraoperatif serta penggunaan hemofilter masih kontroversial. Penelitian ini bertujuan untuk mempelajari efek hemofilter, pemberian preoperatif dan intraoperatif metilprednisolon terhadap komplikasi paska bedah jantung terbuka. Penelitian ini merupakan studi eksperimental dengan desain Prospective Randomized Open-Blinded Evaluation (PROBE). Didapatkan 95 pasien yang menjalani bedah jantung terbuka di Rumah Sakit 
Umum Pusat Dr. Sardjito, Yogyakarta, dan Pusat Jantung Terpadu Rumah Sakit Umum Pusat Dr. Cipto Mangunkusumo, Jakarta, pada periode waktu Desember 2011 hingga Mei 2012. Pasien dibagi menjadi 2 grup yaitu grup A (48 pasien) menerima metilprednisolon intraoperatif $(15 \mathrm{mg} / \mathrm{kg})$, metilprednisolon praoperatif $(5 \mathrm{mg} / \mathrm{kg}$ ), dan hemofilter (kelompok A) dan grup B (47 pasien) menerima metilprednisolon intraoperatif $(15 \mathrm{mg} / \mathrm{kg})$ saja. Dari total 95 pasien, didapatkan $26(27,4 \%)$ sampel mengalami komplikasi $(27,4 \%)$ yang terdiri dari 19 pada kelompok B $(40,4 \%)$ dan 7 pada kelompok B (14,6\%). Perbedaan terjadinya komplikasi ini berbeda nyata ( $\mathrm{p}<0.05 ; \mathrm{OR}=3,97 ; 95 \% \mathrm{Cl}=1,476-10,71)$. Risiko komplikasi menurun $63,9 \%$ pada kelompok A dibandingkan dengan kelompok B dengan hazard ratio 3,2. Dapat disimpulkan bahwa penggunaan hemofilter, pemberian metilprednisolon preoperatif dan intraoperatif dapat menurunkan risiko komplikasi paska bedah jantung terbuka.

Keywords: hemofilter-methylprednisolone-complication -open heart surgery-intraoperative

\section{INTRODUCTION}

The mortality rate related to open heart surgery has declined since the improvements of procedure, preoperative, and postoperative preparation. However, complications of open heart surgery are still threatening patient's survival such as cardiac rhythm and contractile disturbance, electrolyte imbalance, renal, pulmonary, gastrointestinal, hematopoietic, and central nervous system function disturbance. ${ }^{1}$

Cardiopulmonary bypass is a technique which been used in open heart surgery to take over the function of the heart and maintain the circulation of blood which distinguish heart surgery from other surgery. Unfortunately, some complications may follow this procedure, such as vasospasm, altered platelet-endothelial cell interactions, and systemic inflammatory response due to contact of blood and synthetic surface of bypass equipment. It may lead to declining level of microcirculation of heart, brain, and other organs, which may cause organ dysfunction. ${ }^{2}$ Complication is one of the leading cause of death in open heart surgery. It also may cause morbidity and increase the length of hospital stay. ${ }^{1}$ The use of hemofilter in cardiopulmonary bypass machine may reduces systemic fluid overload after cardiac surgery and prevents several complications. ${ }^{3}$

Corticosteroid prophylaxis in heart surgery has been studied for several years, however its role remains controversial. ${ }^{4-8}$ Several mechanisms of corticosteroid's benefit on patient who required cardiopulmonary bypass have been shown on prior studies. They may include reduction in the expression of endothelial molecule, improvement in myocardial and pulmonary cell integrity, cytokine release, and complement activation. ${ }^{9}$ Corticosteroid may be an effective method to reduce open heart surgery complications related to the inflammatory response., ${ }^{4,6}$ However, another study has reported that administration of intraoperative methylprednisolone prophylaxis only has not been shown to reduce surgical complications. ${ }^{10}$ Therefore, in this study we wished to analyze the effect of preoperative and intraoperative methylprednisolone and application of hemofilter on complications after open heart surgery. 


\section{MATHERIALS AND METHODS}

\section{Design and subjects}

We conducted an experimental study using Prospective Randomized Open-Blinded Evaluation (PROBE) design. This study took place at Dr. Sardjito General Hospital, Yogyakarta and Dr. Cipto Mangunkusumo General Hospital, Jakarta within the period of December 2011 until May 2012. The ethical clearance of this study has been approved by the Medical and Health Research Ethic Committee, Faculty of Medicine, Universitas Gadjah Mada/Dr. Sardjito General Hospital, Yogyakarta (Ref. KE/FK/768/EC) and Faculty of Medicine, Universitas Indonesia/Dr. Cipto Mangunkusumo General Hospital, Jakarta (Ref. 364/PT02.FK/ETIK/2012).

The subjects were above 18 years old and diagnosed with a heart defect, and underwent open-heart surgery at Dr. Sardjito General Hospital, Yogyakarta and integrated the Cardiac Center of Dr. Cipto Mangunkusumo General Hospital, Jakarta. The subjects were divided into two groups using block randomization i.e. Group A, the patients were treated with intraoperative methylprednisolone $(15 \mathrm{mg} / \mathrm{kg})$, preoperative methylprednisolone $(5 \mathrm{mg} / \mathrm{kg})$ and hemofilter and Group B, the patients were treated with intraoperative methylprednisolone $(15 \mathrm{mg} /$ $\mathrm{kg}$ ) only.

\section{Experimental procedure}

Complication was measured as morbidity such as myocardial infarction, lung function disturbances, kidney function disturbance, and postoperative infection which happened within 30 days post-surgery. Myocardial infarction (MI) was a necrosis of cardiac myocyte due to insufficient oxygen and blood perfusion and measured by ECG and Troponin I level. Pathologic Q wave and STsegment elevation was measured as a sign of cardiac muscle necrosis. Troponin I marker was measured twice: before surgery and 3 hours after surgical wound closure finished. Troponin I level was labeled as abnormal if the level was $>0.1 \mathrm{ng} / \mathrm{mL}$. ECG was monitored on Marquet invasive monitor during the surgical procedure and post-surgical care in ICU.

Pulmonary function disturbance was a decreasing in pulmonary function, measured by blood gas analysis and chest X-ray. Blood gas analysis was measured 4 times on 3, 24, 48 and 72 hours post-surgery. Blood gas analysis was labeled as abnormal if $\mathrm{PaO}_{2}<80$ $\mathrm{mmHg}, \mathrm{Pa} \mathrm{CO}_{2}<32 \mathrm{mmHg}$, or $>45 \mathrm{mmHg}$, $\mathrm{pH}<7.35$, or $\mathrm{pH}>7.45$. Chest X-ray was done in anteroposterior projection as much as 4 times on 3 and 24 hours post-surgery, on hospital discharge, and on follow up in clinic. Chest X-ray was labeled as abnormal if there was a sign of pulmonary edema, hemothorax, pneumothorax, pleural effusion, or pneumonia/ bronchopneumonia. Kidney function disturbance was a decreasing in kidney function measured as a decreasing in urine output below the level of $0.5 \mathrm{cc} / \mathrm{kg} /$ hour, or blood creatinine level $\geq 1.5 \mathrm{mg} / \mathrm{dL}$. Any signs of infection within 30 days post-surgery on surgical wound, pericardium, or lung was noted as postoperative infection and recorded in a medical record.

\section{Statistical analysis}

We compared the mean values of continuous variables using independent t-test or analysis of variance (Anova). Categorical variables were analyzed using Chi-square or Fisher exact test. Analysis of survival, free of complications and mortality figures was calculated using the Kaplan-Meier method and the log rank test curve. Comparison of survival, complication-free numbers and mortality rate between the two groups was performed with the log-rank test. 


\section{RESULTS}

During the 6 months period, 96 patients were ascertained in this study. We found one incomplete data and excluded it from the study. Finally, 95 patients were analyzed consisted of 48 patients of the group A, and 47 patients of the group B. The baseline characteristics between the group A and group B were not statistically different $(\mathrm{p}>0.05)$ as shown in TABLE 1.

TABLE 1. Subject baseline characteristic between treatment groups

\begin{tabular}{|c|c|c|c|c|}
\hline Variable [n (\%)] & $\begin{array}{c}\text { Group A } \\
{[48(50.5)]}\end{array}$ & $\begin{array}{c}\text { Group B } \\
{[47(49.5)]}\end{array}$ & $\begin{array}{c}\text { Total } \\
{[95(100)]}\end{array}$ & $\mathbf{p}$ \\
\hline \multicolumn{5}{|l|}{ Age (Years) } \\
\hline$\geq 30$ & $39(81.3)$ & $41(87.2)$ & $80(84.2)$ & 0.451 \\
\hline$<30$ & $9(18.7)$ & $6(12.8)$ & $15(15.8)$ & \\
\hline \multicolumn{5}{|l|}{ Sex } \\
\hline Male & $26(54.2)$ & $22(46.8)$ & $48(50.5)$ & 0.473 \\
\hline Female & $22(45.8)$ & $25(53.2)$ & $47(49.5)$ & \\
\hline \multicolumn{5}{|l|}{ NYHA class } \\
\hline Two & $33(68.8)$ & $27(57.4)$ & $60(63.2)$ & 0.239 \\
\hline Three & $15(31.3)$ & $18(38.3)$ & $33(34.7)$ & \\
\hline Four & 0 & $2(4.3)$ & $2(2.1)$ & \\
\hline \multicolumn{5}{|l|}{$\mathrm{Hb}$} \\
\hline Abnormal & $3(6.7)$ & $1(2.3)$ & $4(4.5)$ & 0.617 \\
\hline Normal & $42(93.3)$ & $42(97.7)$ & $84(95.5)$ & \\
\hline \multicolumn{5}{|l|}{ Creatinine } \\
\hline Abnormal & $19(42.2)$ & $15(35.7)$ & $34(39.1)$ & 0.534 \\
\hline Normal & $26(57.8)$ & $27(64.3)$ & $53(60.9)$ & \\
\hline \multicolumn{5}{|l|}{ Ureum } \\
\hline Abnormal & $7(16.3)$ & $2(4.7)$ & $9(10.5)$ & 0.156 \\
\hline Normal & $36(83.7)$ & $41(95.3)$ & $77(89.5)$ & \\
\hline \multicolumn{5}{|l|}{ Albumin } \\
\hline Abnormal & $3(6.7)$ & $4(9.5)$ & $7(8.0)$ & 0.707 \\
\hline Normal & $42(93.3)$ & $38(90.5)$ & $80(92.0)$ & \\
\hline \multicolumn{5}{|l|}{ Random Glucose test } \\
\hline Abnormal & $3(6.8)$ & $7(16.7)$ & $10(11.6)$ & 0.191 \\
\hline Normal & $41(93.2)$ & $35(83.3)$ & $76(88.4)$ & \\
\hline \multicolumn{5}{|l|}{ Kalium } \\
\hline Abnormal & $4(9.3)$ & $2(4.8)$ & $6(7.1)$ & 0.676 \\
\hline Normal & $39(90.7)$ & $40(95.2)$ & 79 (92.9) & \\
\hline \multicolumn{5}{|l|}{ Natrium } \\
\hline Abnormal & 5 (11.6) & $2(4.8)$ & $7(8.2)$ & 0.433 \\
\hline Normal & $38(88.4)$ & $40(95.2)$ & 78 (91.8) & \\
\hline \multicolumn{5}{|l|}{ Magnesium } \\
\hline Abnormal & $2(4.9)$ & $6(16.7)$ & $8(10.4)$ & 0.137 \\
\hline Normal & $39(95.1)$ & $30(83.3)$ & 69 (89.6) & \\
\hline \multicolumn{5}{|l|}{ Calcium } \\
\hline Abnormal & 0 & $3(8.3)$ & $3(4.0)$ & 0.106 \\
\hline Normal & 39 (100) & $33(91.7)$ & $72(96.0)$ & \\
\hline
\end{tabular}


We found $26 \quad(27.4 \%)$ complication incidence, among them 19 were the group $\mathrm{B}$ and 7 were group A. The most frequent complication was pleural effusion $(38.5 \%)$ and pulmonary edema $(34.6 \%)$. We found no significant correlation between each type of complication and treatment groups $(\mathrm{p}>0.05)$ as shown in TABLE 2.

TABLE 2. Distribution of complications following open heart surgery

\begin{tabular}{lcccc}
\hline \multicolumn{1}{c}{ Complication } & $\begin{array}{c}\text { Group A } \\
(\mathbf{n = 4 8 )}\end{array}$ & $\begin{array}{c}\text { Group B } \\
(\mathbf{n = 4 7 )}\end{array}$ & $\begin{array}{c}\text { Total } \\
{[\mathbf{n = 9 5} \text { or }} \\
\mathbf{1 0 0 \%}]\end{array}$ & $\mathbf{p}$ \\
\hline Pulmonary edema & 2 & 7 & $9(34.6)$ & 0.0744 \\
Pleural effusion & 3 & 7 & $10(38.5)$ & 0.1497 \\
Stroke & 1 & 0 & $1(3.8)$ & 0.5053 \\
AV Block & 1 & 1 & $2(7.7)$ & 0.7474 \\
Wound infection & 0 & 2 & $2(7.7)$ & 0.2421 \\
Pneumonia & 0 & 1 & $1(3.8)$ & 0.4947 \\
Low cardiac out put & 0 & 1 & $1(3.8)$ & 0.4947 \\
\hline Total & 7 & 19 & 26 & \\
\hline
\end{tabular}

We analyzed the incidence of postoperative complications between the group A and group B. Analysis using Chi-square showed that postoperative complication to group A was significantly lower compared to group B $(\mathrm{p}<0.05 ; \mathrm{OR}=3.97 ; 95 \% \mathrm{CI}=1.476-10.71)$, indicating that the group B may experience complications almost 4 times higher than compared to those in the group A (TABLE 3).

TABLE 3. Incidence of post-operative complications in group A and B

\begin{tabular}{|c|c|c|c|c|c|}
\hline \multirow[t]{2}{*}{ Group } & \multicolumn{3}{|c|}{$\begin{array}{c}\text { Complication } \\
{[\mathrm{n}(\%)]}\end{array}$} & \multirow[t]{2}{*}{ OR (95\%CI) } & \multirow[t]{2}{*}{$\mathbf{p}$} \\
\hline & Yes & No & Total & & \\
\hline $\mathrm{A}$ & $19(73.1)$ & $28(40.6)$ & $47(49.5)$ & $3.97(1.476-10.71)$ & 0.005 \\
\hline $\mathrm{B}$ & $7(26.9)$ & $41(59.4)$ & $48(50.5)$ & 1 & \\
\hline
\end{tabular}

The result of Kaplan-Meier analysis showed that incidence of complications of the group A compared to the group B was statistically different $(p<0.004)$ and hazard ratio $=3.2$, which meant the group B was 3.2 times more likely to develop complications within 30 days compared to the group A (FIGURE 1). 


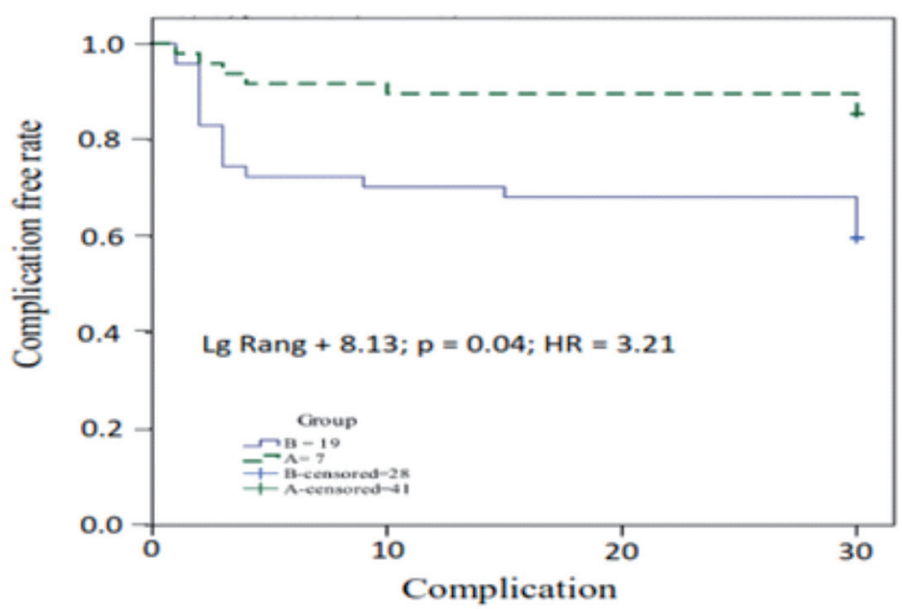

FIGURE 1. Kaplan Meier graphic of the group A and B toward complication

Comparative analysis between both groups on the incidence of complications showed that treatment the group A's complication risk decreased by $63.9 \%$ compared to the treatment group B (TABLE 4).

TABLE 4. Analysis of relative risk ratio (RRR) of complication event between groups

\begin{tabular}{cccccc}
\hline \multirow{2}{*}{ Groups } & \multicolumn{3}{c}{ Complication [n (\%)] } & \multirow{2}{*}{ OR (95\% CI) } & p \\
\cline { 2 - 4 } & Yes & No & Total & & 0.005 \\
\hline Group A & $7(26.9)$ & $41(59.4)$ & $48(50.5)$ & $0.25(0.08-0.74)$ & 0.00 \\
Group B & $19(73.1)$ & $28(40.6)$ & $47(49.5)$ & 1 & \\
\hline
\end{tabular}

$\mathrm{RRR}=0.639(0.223-0.833) ; \mathrm{ARR}=0.258(0.079-0.419) ; \mathrm{NNT}=3(13-2)$

\section{DISCUSSION}

This study showed that the incidence of complications was lower in the group A than the group B. Evidence suggests that the administration of prophylaxis corticosteroids is effective in reducing cardiac surgery complication, especially atrial fibrillation. ${ }^{4,11}$ Furthermore, the administration of preoperative systemic steroid may give benefit in reducing postoperative ICU and hospital stay due to complication. ${ }^{12,13}$ Pleural effusion is the most frequently observed complication. Postoperative pleural effusions are commonly found in patients who undergo open heart surgery. About $10 \%$ of the patients who undergo cardiac surgery develop a pleural effusion. ${ }^{14}$

Cardiac surgery and cardiopulmonary bypass induce systemic acute inflammatory response and fluid overload, which may contributes to postoperative complications. ${ }^{3,4}$ The administration of methylprednisolone may prevent complications related to this inflammatory response. ${ }^{4}$ Fluid overload can be removed using hemofilter. ${ }^{3}$ However, the administration of methylprednisolone alone 
cannot overcome the fluid overload and the use of hemofilter alone is inadequate in reducing inflammatory response. ${ }^{15}$

The group B was more likely to develop complications compared to the group A. Furthermore, risk of complications in the group A was significantly decreased. Decreased incidence of complications in this study is much higher compared to prior study. ${ }^{16}$ These results clearly support the use of combined methylprednisolone and hemofilter in cardiac surgery with cardiopulmonary bypass as the solution for preventing postoperative complications. Combination of methylprednisolone administration and hemofilter application can reduce both inflammatory response and fluid overload after cardiac surgery using cardiopulmonary bypass, which contribute to significant prevention of many postoperative complications.

\section{CONCLUSION}

The combination of hemofilter application, preoperative and intraoperative administration of methylprednisolone might decrease the risk of complications after open heart surgery

\section{ACKNOWLEDGEMENTS}

We would like to thank all patients who have participated in this study. We also would like to thank Mrs. Dewi Ismimasitoh from Clinical Epidemiology and Biostatistics Unit (CEBU), Faculty of Medicine, Universitas Gadjah Mada, Yogyakarta for assisting in this study.

\section{REFERENCES}

1. Williams JF Jr, Morrow AG, Braunwald E. The incidence and management of "medical" complications following cardiac operations.
Circulation 1965; 32(4):608-19. http://dx.doi. org/10.1161/01.CIR.32.4.608

2. Cameron D. Initiation of white cell activation during cardiopulmonary bypass: cytokines and receptors. J Cardiovasc Pharmacol 1996; 27(1):1-5. http://dx.doi. org/10.1097/00005344-199600001-00004

3. Grunenfelder J, Zund G, Schoeberlein A, Maly FE, Schurr U, Guntli S, et al. Modified ultrafiltration lowers adhesion molecule and cytokine level after cardiopulmonary bypass without clinical relevance in adults. Eur $\mathrm{J}$ Cardiothorac Surg 2000; 17(1):77-83. http:// dx.doi.org/10.1016/S1010-7940(99)00355-3

4. Ho KM \& Tan JA. Benefits and risks of corticosteroid prophylaxis in adult cardiac surgery: a dose-response meta-analysis. Circulation 2009; 119(14):1853-66. http:// dx.doi.org/10.1161/CIRCULATIONAHA. 108.848218

5. Keski-Nisula J, Pesonen E, Olkkola KT, Ahlroth T, Puntila J, Anderson S, et al. Highdose methylprednisolone has no benefit over moderate dose for the correction of tetralogy of fallot. Ann Thorac Surg 2016;102(3):870-6. doi:10.1016/ J.ATHORACSUR.2016.02.089.

6. WhitlockRP, Devereaux PJ, Teoh KH,LamyA, Vincent J, Pogue J, et al. Methylprednisolone in patients undergoing cardiopulmonary bypass (SIRS): a randomised, doubleblind, placebo-controlled trial. Lancet 2015;386(10000):1243-53. doi:10.1016/ S0140-6736(15)00273-1.

7. Al-Shawabkeh Z, Al-Nawaesah K, Anzeh RA, Al-Odwan H, Al-Rawashdeh WAB, Altaani H. Use of short-term steroids in the prophylaxis of atrial fibrillation after cardiac surgery. J Saudi Hear Assoc 2017;29(1):2329. doi:10.1016/J.JSHA.2016.03.005.

8. Keski-Nisula J, Pesonen E, Olkkola KT, Peltola K, Neuvonen PJ, Tuomnen N, et al. Methylprednisolone in neonatal cardiac surgery: reduced inflammation without 
improved clinical outcome. Ann Thorac Surg 2013; 95(6):2126-32. doi:10.1016/J. ATHORACSUR.2013.02.013.

9. Warren OJ, Watret $\mathrm{AL}$, de Wit $\mathrm{KL}$, Alexiou C, Vincent C, Darzi AW, et al. The inflammatory response to cardiopulmonary bypass, part 2: anti-inflammatory therapeutic strategies. J Cardiothorac Vasc Anesth 2009; 23(3):384-93. http://dx.doi.org/ 10.1053/j. jvca.2008.09.007

10. Elbarbary M, Madani WH, Robertson-Malt S. Prophylactic steroids for pediatric open heart surgery. Cochrane Database Syst Rev 2015; 2017(5). doi:10.1002 /14651858.CD005550. pub3.

11. Cappabianca G, Rotunno C, De Luca Tupputi Schinosa L, Ranieri VM, Paparella D. Protective effects of steroids in cardiac surgery: A meta-analysis of randomized double-blind trials. J Cardiothorac Vasc Anesth 2011; 25(1):156-65. doi:10.1053/ j.jvca.2010.03.015.

12. Light RW. Pleural effusions after coronary artery bypass graft surgery : current opinion in pulmonary medicine. Curr Opin Pulm Med,
2002; 8(4):308-11. http://journals.lww.com/ copulmonarymedicine/Abstract/2002/07000/

13. Light RW. Pleural effusions after coronary artery bypass graft surgery. Curr Opin Pulm Med 2002; 8(4):308-11. http://dx.doi. org/10.1097/00063198-200207000-00011

14. Starobin D, Kramer MR, Garty M, Shitirt D. Morbidity associated with systemic corticosteroid preparation for coronary artery bypass grafting in patients with chronic obstructive pulmonary disease: a case control study. J Cardiothorac Surg 2007; 4(2):25. http://dx.doi.org/10.1186/1749-8090-2-25

15. Gutierrez T, Hornigold R, Pearce A. The systemic response to surgery. Surgery 2014; 32(3):149-52. doi:10.1016/J. MPSUR.2013.12.013.

16. Luciani GB, Menon T, Vecchi B, Auriemma S, Mazzucco A. Modified ultrafiltration reduces morbidity after adult cardiac operations. Circulation 2001; 104(12 Suppl 1):1253-9. http://dx.doi.org/10.1161/hc37t1.094931 